\title{
Lakatosian Perspective of Islamic Science Research Programmes (Case: Islamization in Welfare Theory)
}

\author{
M. Kholid Muslih', Nur Hadi Ihsan², Usmanul Khakim³ ${ }^{3}$, Winda Roini ${ }^{4}$ \\ \{kholid.muslih@gmail.com ${ }^{\mathrm{I}}$, nurhadiihsan@gontor.ac.id², usmanulhakim680@gmail.com², \\ windaroini621@gmail.com $\left.{ }^{4}\right\}$ \\ ${ }^{1,2,3,4}$ University of Darussalam (UNIDA) Gontor, Jl. Demangan Siman Ponorogo Jawa Timur, Indonesia
}

\begin{abstract}
Islamization is projected to build Islamic science in accordance with the lives of Muslims; requires tangible scientific or technological products. Therefore, the methodology of Islamic scientific research program is an urgent need today. Therefore, this paper is concerned with simulating the Lakatosian Islamic science research program towards Islamization in the economic field, namely the meaning of welfare. This research a library and qualitative research; data were analyzed by contain interpretation, and critical analysis. As a finding, the Lakatosian Islamic science program was successfully simulated in the Islamization of the theory of welfare. The implication is to strengthen the Lakatosian Islamic scientific research program as a method of research programs at Islamic Universities.
\end{abstract}

Keywords: Islamization of science, Lakatos, methodology of scientific research program, welfare theory

\section{Introduction}

According to Adi Setia, Islamic science has three definitions [1]. First, Islamic science as a scientific discipline that examines the history of science and technology in Islamic civilization. Second, Islamic science as a discipline that examines the philosophy of science to formulates the concepts and methodologies; that should be the guide at every activities in Islamic civilization. Third, Islamic science as a project of research programmes. The project is experimental, practical and empirical which aims to implement the Islamic value and vision in all scientific activities and technology.

Refer to three definitions of Islamic sciences above, it can be said that the bigest challenge today is in the third definition of Islamic science; namely the formulation of scientific discipline in research project. As the reason, as long as this challenge was failing to complete, as long as the Muslim scientists will be trapped in Western scientific frameworks. [2] Therefore the keyword of this challenge is to formulate an "experimental research agend $a^{\prime \prime}$; furthermore, without the existence of the clear research concept agenda, the first and second definitions of Islamic science became meaningless.

In formulating the agenda, some scholars have seen that Islamization can be translated by Methodology of Scientific Research programmes Imre Lakatos. For example, Adi Seti has started this agenda faithfully. This program is contained in his work "Dewesternizing\& Islamizing the Sciences: Operationalizing the Neo-Ghazalian, Attasian Vision”, [1]. Mohammad Muslih has continued the effort of AdiSetia. His dissertation in UIN Yogyakarta 
under title PengembanganSains Islam dalamPersepektif Metodologi Program Riset Lakatosian more clearly confirms the different areas of Islamic science, he called the area of theory, paradigm, and scientific theology. Both of these scholars who have Lakatosian school succeeded in formulating the Islamic science building and detailing the sections, but they have not yet discussed how was the Islamization applied inside. Therefore, this research will try to simulate the steps of Islamization of science; then will be applied to the case of welfare theory.

\section{Research methods}

This research is a library research [3] with qualitative data [4]. Specifically this research also be called as R\&D research (Research and development) [4]. The purpose of this research is arranging the steps of Islamic research science; and try to apply it into the welfare theory of a case. Therefore, the primary data to develop Islamic science research programmes will be obtained from Imre Lakatos, under the title "The Methodology of Scientific Research Program" [5], and as secondary data will be extracted from the various books relating to the Lakatos' research program. To clarify the discussion, Islamization measures need to be examined on a case object. Therefore, the case object of this research is a the book; " Mendudukkan Kembali Makna Kesejahteraan dalam Islam" by Satria Hibatal Azizy. Data analysis methods are done with contain analysis [6]. While the writing systematics will begin with a brief presentation of the methodology of research programmes Lakatos as the result of data research, then discussion and analysis of Lakatos research program to composing the steps of Islamic research programmes of lakatosian perspective and examine it in the case of Islamization -theory of welfare, so concluding and giving the suggestions.

\subsection{Methodology of Lakatos Research Program}

ImreLakatos, or ImreLipschitz, born in Hungary 1922, resides in Vienna and London. hewas a scientist pursuing of mathematics, physics and philosophy. [7] He earned his Ph.D. degree in 1961 by maintaining his dissertation under the title "Essays in Logic of Mathematical Discovery" at Cambridge University. Then he shifted his study into philosophy of science and got his momentum when he was 1965 in the symposium that unite Kuhn's thought and Popper which be called asthe methodology of research program. What he meant by the methodology of research programs is as a methodological structure that provides guidance for future research in a positive and negative way; An alternative thought to be assured of advances in scientific theory as well as bridging the thinking of Thomas S Kuhn (shift of paradigm) and Karl Popper (falsification), which is to provide the deepest space for the bases of metaphysical science, that are fixed and cannot be shifted. This is the advantage of the Lakatos' research programmes. This research program contains three elements, they are hard-core, a protective-belt, and a series of theories [5]. So here they are the explanation:

First, the hard-core (as a core essence) as the basic assumption which is unchanged and should be protected from falsification threats. In the rule of methodology, a hard-core is called as a negative heuristic, because the solid core of the fundamental assumption should not change, functioning as the base core of the other elements. Hard-core should be retained for its integrity as long as the program is still running, the consequence if a scientist conducts modifications to the hard-core, then he has actually been out of the research program done [5]. 
Second, the protective-belt consisting of auxiliary hypotheses in the initial state is referred to as a positive heuristic to protect the underlying core of various attacks, but this circle in testing and changing. Its more vague and harder to detail unlike a clear, fixed hard-core [5].

Thirdly, the series of theories, which is the linkage of the theory in which the next theory is the result of auxiliary clauses added from previous theories. According to Lakatos scientific or non-scientific is not standardsin a single theory, but consist of the series of several theories. the consequence is to entrust continuity between one theory and that will be developed with the previous theory that is considered well established. In other words, each is a result of adding additional clauses to the previous theory. [5]

The important thing of this series theories is signed by the definite continuity. The Scientific research program is characterized by; (1) must meet the degree of coherence that contains definite planning for subsequent research programs; (2) must be able to produce new phenomenon discovery. [7] The success of the research program is seen from the progress of science progressively, and it is said to fail if only resulted in a deteriorating problem. Nevertheless, that failure would benefit the sustainability of the opposite theory.

\subsection{Lakatosian Research Program of Islamic Science}

As has been stated before that in Lakatos research programmmes there are 3 component. they are hard-core, protective-belt and a series of theories. If trying to be attributed to building an Islamic science research then these three components can be described in three circles, as follows:

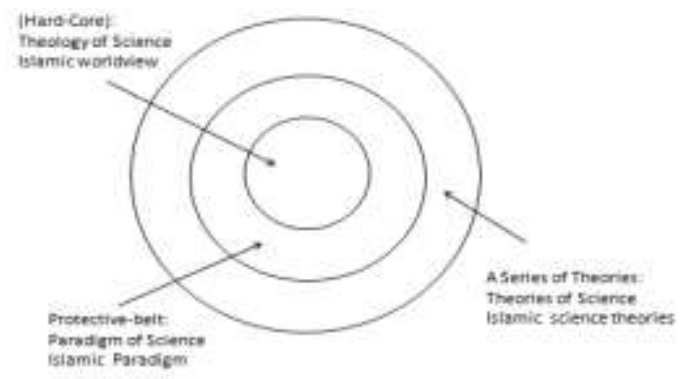

Fig. 1. Architecture of Lakatosian Islamic Science

First, the inner circle illustrates the metaphysical essence that is unchanged and fixed or can be called as the main framework that is irreversible and disrupted. Adi Setia stated that this main framework contains the core elements of Islamic vision (Islamic worldview) (Setia,2008). The definition of Islamic Worldview according to Al Attas is the Islamic vision of reality and truth; or Islamic view of the fact that occurs behind the genesis of nature, as explained in the Qur'an and Sunnah which is the affirmation of intellectual and intuitive principles [8]. Islamic worldview covers a variety of key concepts such as God, religion, ethics, science, reality, happiness etc. According to Mohammad Muslih this field is referred to as the theological area of science [7].

Secondly, the protective-belt is a hypothesis layer that is tasked with protecting the parent concept. According to Muhammad Muslih This coating is referred to as the paradigm of science [7]. The characteristics of this coating are negative, passive, reactive and apologetic. [1]. This is where there is a theoretical clash of a theory, where one paradigm can be shifted or replaced by other paradigms after the old paradigm is filled with anomalies, sift of 
paradigm according to the term of Thomas Kuhn [9]. In conjunction with the Islamic science research program, on this layer, a Muslim scientist in charge (1) examines the paradigm or hypotheses that basic assume of a theory. (2) Replace the hypothesis with hypotheses sourced from the Islamic worldview in the main layer. That is the new hypothesis which become the fundamental assumption of building a new theory.

Third, is the concept of a roadmap that contains a series of theories. This layer of characteristics is active, creative and productive in establishing a new theory by looking for an auxiliary clause from the existed theory in the region. This layer contains a series of theories closely related to each other. In addition, the new theory also got a helpful clause from empirical proving in the field. Adi Setia stated that this layer is the birthplace of new theories. [10]. The same is expressed by Muhammad Muslih which refers to this region as a theoretical area of science [7].

After observing the Lakatosian Islamic science building, it can be understood that the process of Islamization of a theory occurs only on the two outer layers that are layers of theory of science and paradigm of science, and should not occur in the theological layer of science. For easier steps, Islamization theory can be sorted as follows; First, analyze the impact of early theory. This step is to demonstrate that a theory is irrelevant, is negative, incomplete, harmful or even destructive. Essentially repeat at the conclusion that early theories are problematic [4]. This applies to the most outer layers of science theory. Second, it finds the early theory paradigm. After it was stated that the initial theory was problematic, the next task was to dismantle the paradigm by investigating the hypotheses that assumed the basic theory was built. Third, find a new hypothesis by conducting a survey on the Islamic worldview that is in the deepest circle and setting it as a substitute for the initial hypothesis. This new paradigm is the basis of new theory. This second and third step occurs in the second layer of the Science paradigm area. Fourth, builds a new theory based on a new paradigm that has been replaced. In building a new theory it requires an auxiliary clause of the old theories that are under the same paradigm that had already existed; In addition to the help clause of the discoveries in the field. It was born a new theory that has been through the process of Islamization.

\subsection{Case: Islamization on the welfare theory}

After discussing, it is necessary to make a simulation related to the Islamic science research project in a real application. The following will be shown a simulation of the research method of designing LakatosianIslamic research for welfare meaning. As the object of the case will be critilizing the meaning of the meaning of welfare in Islam by Satria Hibatal Azizy [11]. Here's the description:

\subsubsection{Analyzing the problem/impact of early theory}

The process of Islamization begins by revealing the meaning of welfare both in language and in terms. In modern science the language of welfare means health, comfort, happiness of individuals or society [12]; free Disease-free suffering [13]. In terms as Goodin expressed that welfare is the fulfillment of economic needs, avoid poverty and common social equality and stability and realization of autonomy [14]. Then the indication of welfare by United Nations (UN) is measured through the Human Development Index (HDI) with three aspects of life expectancy, the level of education and the standard level of living. [15] In short, the country that has high HDI level is the most prosperous country. 
However, as Azizy said that the country with a high level of welfare does not necessarily make its citizens appreciate life. [11] Even criminality is still quite high such as murder, sexual harassment and various other crimes. [11]. This certainly turned around with what should be the more prosperous a community, the better behavior. Therefore, Aziz concluded that the meaning of welfare offered by modern science needs to be reform. If viewed from the Lakatosian Islamic research program framework, Aziz has actually done the first step of finding the problem in a theory.

\subsubsection{Finding a theoretical paradigm}

The next process is to review the meaning of modern well-being to find the paradigm, basic assumptions and hypotheses that the theory has built. Aziz states that the significance of prosperity in modern science is oriented to the material [11]. The statement can be explained that one is said to be prosperous when material or physical needs are fulfilled. This is the fundamental assumption of the modern welfare theory. While the hypothesis is wealth, physical health and security are instruments of welfare. If the basic assumption and hypothesis a theory of orientation to physical material can be said that the paradigm of that theory is materialistic. Here it begins to appear that the theory built on the modern welfare theory is the positivity paradigm. To make welfare theory in the Islamic science framework, the paradigm must be replaced; Because it is indeed a positivity paradigm is not in accordance with the paradigm of Islam that affirmation of physical and metaphysical perspectives, dunyawi and ukhrowi.

\subsubsection{Shifting of the paradigm}

After finding that the early theory paradigm is a materialistic paradigm, the Islamization process is continued by changing the paradigm with the Islamic paradigm. This refers to the area called by MohamadMuslih as a theology of science that contains the worldview of Islam. Islamic Worldview offers a paradigm of Islam whose content that prosperity in Islam must be in the two-dimensional dunya (physical world) and akherat (metaphysical-world) [8]. The hypothesis is that prosperity in the hereafter is the real purpose and the world is preparation to get there. This means that the world and the hereafter are both noticed by Islam. In this case, Aziz has replaced the positivity paradigm and laid the paradigm of Islam as the basic theory. He stated that Islam sees prosperity in two dimensions, namely the dunyawi and ukhrawi dimension, where the ukhrawi dimension is more dominant in the determination of human welfare [11]. The paradigm of this new theory will be built.

\subsubsection{Building a new theory}

The next step is to build a new theory based on Islamic paradigms. According to Azizy, the concept of stating in Islam that prosperity encompasses the dunyawi (sensory world) and ukhrowi (non-sensory world) is summarized in the concept of falah. It means that Aziz has found the concept to be developed into theory by adding auxiliary clauses from other theories. This is in accordance with the Lakatosian Islamic science research rules.

Falah means the winner [16] or in good condition (Manzur, Lisan al Arab). While the term can be seen in two dimensions namely dunyawi and ukhrowi. In the temporal (dunyawi) dimension, Falah is interpreted survival, freedom, strength and honor. Further, in the dimension of Ukhrawi, falah interpreted eternal survival, everlasting welfare, glory and everlasting knowledge [17]. In brief, Falah will lead to conditions in 4 aspects namely 
spiritual, economic, cultural and political. On the spiritual aspect will deliver person in worship, piety, zikrullah, taqwa and tazkiyatunnafs. On economic aspects will lead to use of wealth for social welfare, Infaq and zakah, avoiding riba, maintaining trust, eliminating exploitation, hard work and philanthropic. In the social aspect, falah will push on the good environment for worship, greed, sexual chastity, loss of drunkenness, gambling, crime, environmental hygiene and manners. In terms of politics, falah implicates the jihad, syura and the role of the state in community welfare. Thus the concept falah and its implications in line with the pragmatism is the welfare in two dimensions. They are dunyawi and ukhrowi.

Furthermore, to be a real theory, the concept of falah obtained clause aids from other theories that are on the same paradigm of Islamic paradigms. In this case Aziz added a theory of maslahah and Maqasid syari'ah. [11] theory of maslahah consisting of primary principles (Dzaruriyat), secondary (Hajiyat) and tertiary (Tahsiniyat), used to measure the falah hierarchical level. And Maqashid shariah which includes the element of preserving religion, soul, reason, property and heredity are used to classify the falah type. Here simply Azizy describes;

Table 1. Falah Theory

\begin{tabular}{|c|c|c|c|}
\hline \multirow{2}{*}{$\begin{array}{c}\text { Syari'at aims } \\
\text { (Maqasid Syariah) }\end{array}$} & \multicolumn{3}{|c|}{ Maslahah } \\
\hline & Dzaruriyat (Primary) & Hajjiyat (Secondary) & Tahsiniyat (Tertiary) \\
\hline Religion protection & $\begin{array}{l}\text { syahadat, shalat, zakat, } \\
\text { Ramadhan fasting, } \\
\text { hajj. }\end{array}$ & $\begin{array}{l}\text { Ibadah } \\
\text { sunnahmu'akkadah }\end{array}$ & $\begin{array}{l}\text { Ibadah sunnah ghairu } \\
\text { muakkadah }\end{array}$ \\
\hline Soul protection & Clothes, meals, drink & $\begin{array}{l}\text { Transportation and } \\
\text { communication tools }\end{array}$ & $\begin{array}{l}\text { Exclusive car ang } \\
\text { house, sophisticated } \\
\text { handphone }\end{array}$ \\
\hline Mind protection & $\begin{array}{l}\text { Basic education, able } \\
\text { to think }\end{array}$ & Studying at collage & Studying abroad \\
\hline Ancestry protection & Avoid adultery & Married & Have the ancestry \\
\hline Treasure protection & $\begin{array}{l}\text { Transaction for daily } \\
\text { needs }\end{array}$ & Shodaqoh, giving & $\begin{array}{l}\text { The giant giving/ } \\
\text { shodaqoh in the big } \\
\text { dealing }\end{array}$ \\
\hline
\end{tabular}

From the table above appears in falah theory, there is a benchmark of welfare that is typical of Islam. A Muslim is required to fulfill falah in the above aspects without neglecting one another. In Islam, it is not prosperous when he is rich in wealth until the tertiary level for example but he likes adultery or not fond of charity. Ideally every Muslim is able to keep the five maqoshid and try to achieve at the highest level of Tahsiniyat. So what Azizy did as revealed Lakatos in the area of science theory one theory will always come together with another theory, build and strengthen each other. 


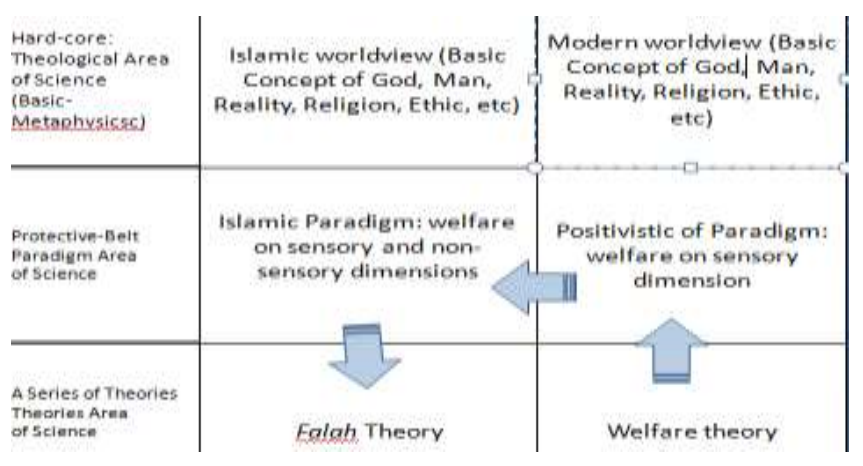

Fig. 2. Islamization steps of welfare theory.

The table above explains that Azizy has been in the process of Islamization through 4 steps. First analyze the problem of welfare theory. secondly, found the welfare theory paradigm; the positivity paradigm. Thirdly, replacing the positivity paradigm with Islamic paradigms. The fourth builds falah theory on the paradigm of Islam. That is, the methodology of Lakatosian Islamic science research program was successfully applied in the Islamization theory of welfare.

\section{Conclusions}

Until here the process of Islamization on the welfare theory has been successful. From the program of Islamic science research perspective, what has been done by Hibatal Azizy have fulfilled the steps of the process of Islamization. In addition, the success of this program is seen when displaying definitive planning for subsequent research programs; Proven with the emergence of 4 steps Islamization; and produce the discovery of a new phenomenon that is falah theory. Falah theory presented by Azizy is the result of the process of Islamization science, and it is worth it to be recommended for the lives of Muslims. It also proved that the Lakatosian Islamic science research program can be applied in the process of Islamization.

As a suggestion, the Islamic science research program has proven to be used, it needs to be carried out continuously proving in various branches of science such as accounting, politics, sociology, agriculture, industry and others; while doing methodological improvements gradually. Therefore, it is not excessive if this program can be taken into account as a new method of research programmes especially in the process of Islamization of science; especially in Islamic universities and muslim researchers. Wallahu'alamBisshawab

\section{References:}

[1] A. Setia, "Dewesternizing \& Islamizing the Science: Operationalizing the NeoGhazalian, Attasian Vision.," in One-Day Colloquium on Islam \& Secularism, Selangor, 2010.

[2] Arif, Syamsuddin, Islamic Science, Paradigm, Fakta dan Agenda, Jakarta: INSIST, 2016.

[3] H. Tavakoli, A Dictonary of Research Methodology and Statistic in Aplied 
Linguistc, Teheran: Rahma Press, 2012.

[4] Sugiyono, Metode Penelitian Kuantitatif, Kualitatif dan R\&D, XIV ed., Bandung: Alfabetha, 2011.

[5] I. Lakatos, Methodology of Scientific Research Programmes, J. Worral, Ed., Cambridge: Cambridge University, 1989.

[6] K. Krippendoff, Content Analysis an Introduction to its Methodology, 2 ed., London: Sage Publication, 2004.

[7] M. Muslih, Pengembangan Sains Islam dalam Perspectif Metodologi Program Riset Lakatosian, Yogyakarta: UIN SUKA Press, 2017.

[8] S. M. N. a. Attas, Prolegomena to the Metaphysiscs of Islam, Kuala Lumpur: ISTAC, 1995.

[9] T. Kuhn, The Structure of Scientific Revolutions, Chicago: Chicago University Press, 1962.

[10] A. Setia, "Tiga Makna Sains Islam: Menuju Pengoperasionalan Islamisasi Sains," Islamia, pp. 47-59, 2008.

[11] S. H. Azizy, Mendudukkan Kembali Makna Kesejahteraan dalam Islam, Ponorogo: CIOS, 2014.

[12] A. Hornby, Oxford Advanced Leqarn's Dictionary of Current English, Oxford: Oxford University Press, 1995.

[13] S. Smith, The New International Webster's Comprehencive Dictionary of the English Language, Florida: Tident Press International, 1996.

[14] R. E. Goodin, The Real Worlds of Welfare Capitalism, Cambridge: Cambridge University Press, 1999.

[15] M. McGillivray, The Human Development Indx: Yet Another Redudant Composite Development Indicator?, Great Britanian: Pergamo Press, 1991.

[16] A. W. Munawwir, Kamus al Munawwir, Surabaya: Pustaka Progresif, 1997.

[17] P. P. E. I. U. I. I. P3EI-UII, Ekonomi Islam, Jakarta: Rajawali Press, 2009.

[18] I. Manzur, Lisan al Arab, Kairo: Darul Maarif, no year. 